beyond biology, and suggesting an evolutionary approach to culture.

However, as Robert Aunger observes in Grafen and Ridley's book: "No significant body of empirical research has grown up around the meme concept ... In fact the memetic literature remains devoted almost exclusively to theoretical antagonisms, internecine battles, and scholastic elucidations of prior writing on memes." Dawkins has essentially left the development of memetics to others. Instead, together with Daniel Dennett, he has used the idea of the meme as a powerful tool in his criticism of religious ideas, which he describes as "viruses of the mind". The effectiveness of the criticism does not much depend on the scientific details of a would-be memetics.

Dawkins' depth and clarity of vision, intellectual honesty and passion, and superb writing have indeed changed the way many of us think about biology. And the latest volume, Richard Dawkins, brings together testimonials and reflections about Dawkins himself or inspired by his work. Most of the contributions, by eminent scientists, philosophers and writers, are laudatory; a few are critical. The book is a pleasant read and throws useful light on the multiform impact of Dawkins' work on biology, philosophy, science writing and the public debate on science and religion. Particularly illuminating are Grafen's chapter discussing the relationship between Dawkins' work and more mathematically oriented population genetics, and Ullica Segerstråle's chapter on Dawkins and sociobiology. Still, in preparing this review, I re-read The Selfish Gene, and this was the real treat.

Dan Sperber is at the Centre National de la

Recherche Scientifique and the Institut Jean Nicod, 1 bis avenue Lowendal, 75014 Paris, France.

\title{
Renaissance magic and mysticism
}

\section{The Devil's Doctor: Paracelsus and the World of Renaissance Magic and Science by Philip Ball \\ Heinemann/Farrar, Straus, Giroux: 2006. 448 pp. $£ 20 / \$ 26$}

\section{Rina Knoeff}

One has to admire Philip Ball's courageous undertaking in writing a biography of Paracelsus, arguably the most controversial medical writer in the Renaissance. Not only are the works of Paracelsus' own hand extremely difficult to read and understand but, more importantly, historical reconstructions of his life and thoughts complicate the picture to such an extent that it is hard to write a 'fair' biography.

Paracelsus is known for being a failed physician; a psychiatric subject in the casebooks of the psychoanalyst Carl Jung; a German national hero during the Nazi period; and the founder of biochemistry. Ball, however, sets Paracelsus in the social, religious and cultural life of his time, a refreshing move away from the tendency to describe early 'scientists' as the forerunners of today's scientific developments

Ball is aware of the historiographic difficulties surrounding the life and work of Paracelsus. His account starts with a brief discussion of how magic and occult forces were accepted parts of early modern science. In addition, Ball acknowledges the close connection between early modern natural philosophy, Renaissance humanism and Reformation religion. In so doing, he follows a fairly recent trend in the history of science and medicine in which religion and science are seen as mutually shaping fields of knowledge.

In The Devil's Doctor, Ball convincingly shows that in order to understand Paracelsus' work and personality we must accept that "in the philosophy of Paracelsus science and rationalism do not compete with mysticism and superstition but blend with it, producing a world that now seems at the B same time wonderful and bizarre". Paracelsus, or Philippus Aureolus Theophrastus Bombastus von Hohenheim, spoke to the imagination. He is said to have ridden a magical white horse, to have cured many incurable diseases, and to have carried an enormous sword with magical powers, as well as the secret elixir of life. His name was linked with those of Faust and Martin Luther, and among the many miracles he allegedly performed was the creation of a living, human-like being.

Today, Paracelsus appears as a hero in the magical world of J. K. Rowling's Harry Potter novels. Yet, perhaps because of the intricate mixture of paracelsian magic, metallurgy, medicine and alchemy, the historical Paracelsus has received comparatively little attention. By presenting the work of Paracelsus, including all the contradictions and neologisms, as an intensely personal enterprise embedded in Renaissance life, Ball circumvents many of the historical difficulties and comes up with an excellent biography that is relevant for historians and general readers alike.

Ball takes events in the life of Paracelsus as starting points for discussing the Renaissance world. For instance, when discussing Paracelsus' life as a vagabond, Ball speaks about the difficulties of travelling in early modern Europe. His discussion of the alchemy of Paracelsus transforms into a discussion of economic growth and the power of miners, and his religious and political views are compared to those of reformers and princes. Ball speaks of Paracelsus' views on astrology in relation to the astronomy of Copernicus and his followers. And last but not least, Ball writes extensively about the traditional (galenic) medicine and chemistry that Paracelsus challenged. The book's illustrations provide a vivid picture of the time and further enliven Ball's account.

This approach is brave and enriching but is also a little overwhelming. At times Paracelsus disappears into the background, and the reader is in danger of getting lost in detailed descriptions of Renaissance culture. Moreover, in a book as ambitious as this it is almost unavoidable that the terminology becomes at times confusing. Much of Paracelsus' work teeters on the brink of the spiritual, and his own vocabulary often seems puzzling to modern readers.

The difficulty in understanding Paracelsus' neologisms and expressions is clearly visible in this book. Ball, for instance, is often wobbly in calling details of Paracelsus' work 'mechanical', 'spiritual' or 'materialistic'. Sometimes it is not clear whether he adopts Paracelsus' own words or gives them a modern, and therefore different, meaning. For example, Ball maintains that Paracelsus' concentration of nature's potencies in the preparation of medicines was "not mechanical” (presumably in a modern sense), but on the next page he states that, according to Paracelsus, the powers of the stars permeate "mechanically" through the Universe (thereby referring to Paracelsus' own words). In both cases Ball refers to the working of invisible powers, but apparently these are mechanical in one case but not in the other, leaving it unclear what Paracelsus meant when he spoke of the mechanical working of the invisible forces of nature. The same goes for the important paracelsian distinction between the material and the spiritual, which at times makes Ball's description of Paracelsus' thoughts somewhat bewildering.

To be fair to Ball, he does explain many of Paracelsus' neologisms, but he also has the 
tendency to follow Jung in maintaining that the language used by Paracelsus must be seen symbolically as an expression of his unconscious mind. It is too easy to argue that, for this reason, the lexicons provided by scholars of Paracelsus must be taken "with a pinch of Paracelsian salt". To my mind, one of the most urgent tasks of the historian is to find out what precisely Paracelsus meant. Without making this effort, the description of his work can only remain superficial.
This criticism notwithstanding, The Devil's Doctor is a fascinating read, rich in content and hugely entertaining. Moreover, it shows that magic was as much at the root of modern science as were the famous discoveries of our modern scientific heroes. It is this awareness that makes Ball's account of Paracelsus essential reading for historians and scientists alike.

Rina Knoeff is in the Faculty of Arts, University of Leiden, 2300 RA Leiden, the Netherlands.

\section{The soldier's tale}

\section{Won for All: How the Drosophila Genome was Sequenced by Michael Ashburner \\ Cold Spring Harbor Laboratory Press: 2006. 107 pp. $\$ 19.95$}

\section{Matt Ridley}

When the history of genome sequencing at the turn of the millennium is written, it will centre on two battles. The battle over the sequencing of the human genome was bigger and more bitter than the one over sequencing the fruitfly genome; if the human genome was Waterloo, Drosophila was barely even Ligny or Quatre Bras. So why would anybody trouble to read, let alone write, a book about the lesser battle?

Michael Ashburner's answer is simple: for the story, not the history. He has written - or rather, he wrote, for these are his immediate reactions, mostly committed to paper at the time - an idiosyncratic, gonzo romp through the crazy days of 1998-99. His purpose, he writes, "frankly, was therapy". This is not like General John Sulston's biographical justification of the genome campaign, The Common Thread, written with Georgina Ferry (National Academies, 2002), or James Shreeve's compendious war report from the camp of Marshal Craig Venter, The Genome War (Alfred A. Knopf, 2004). Rather, this is a field diary from a colonel in the infantry.

The story is by now a familiar one. In 1998 Venter burst into the human genome project, promising to produce a sequence quickly, privately and commercially, thanks to new sequencing machines and the shotgun technique he had used on bacteria. He announced that he would test his method first on fruitflies, winning the cooperation of Gerry Rubin, hitherto the chief sequencer of Drosophila, by promising the immediate release of data. Many arguments later, in November 1999, a flock of scientists gathered to witness an eleven-day 'jamboree', organized mainly by Ashburner, at the Maryland headquarters of Venter's Celera, to find, understand and count the genes in the finished fruitfly sequence.

Ashburner's book covers the year-and-a-half between these two events. It is a time of constant travel for the author: Cold Spring Harbor,
Crete, Florida, Heidelberg, Washington (twice), Iceland (a bird-watching holiday), Heidelberg again, Florida again, Washington, Zurich, Maine, Bloomington, Washington again... I may have missed a few. Being a scientist, Ashburner hates hotels (especially Marriotts), Microsoft, bad coffee and suits - the ones who negotiate on behalf of Celera. He likes or needs sushi, espresso, Lewis Carroll, beer and bouts of bird-watching.

The book rattles along with immediate, chaotic, rambunctious prose, digressing several times on every page into chatty and irreverent footnotes to explain who people are, how and why to find a certain restaurant, or where an aphorism comes from ('Box and Cox' is from an Arthur Sullivan operetta, apparently). Ashburner says that his education in the works of Geoffrey Chaucer taught him the value of footnotes.

The wheels came off the sequencing project on 1 November 1999, when Ashburner was frantically trying to finish several tasks before leaving for the jamboree. On that day, Celera released the fly genome to the NCBI's GenBank database, but with restricted access - to see any sequence, the user had to agree not to copy, re-sell or distribute it. This was not the open access that Venter had promised Rubin the year before. Venter was in a bind, desperate to show his backers that sequence data could have commercial value, and anxious to prevent rivals such as Incyte from selling Celera's data to others. So Venter tried it on. "The best way to find out if he was crossing the line," wrote Shreeve in his history of the event, "was to stick out a toe and see if any alarms went off."

This moment is a little hinge in history. Venter might have got away with it. Rubin was travelling. The NCBI thought this was what had been agreed. It was Ashburner in Cambridge who exploded. His expletive-ridden e-mails sent that afternoon to Rubin and Francis Collins have passed into legend. Rubin was found, Venter confronted. To the fury of Celera's business-development team, Venter backed down, and within 24 hours the fly sequence was freely available on GenBank. Arguably, this was the moment when it became clear that nobody would make serious money from genome sequencing; the pressure to share would prove irresistible. Indeed, given the way the world was going that autumn, maybe it was an omen for the whole 'dot com' frenzy in whose slipstream Celera's share price had accelerated. Celera was not the only overvalued company with a flawed business model for making money out of digital information.

Not that Ashburner portrays himself as a hero or Venter as a villain. The delightful sequel is that within a week of this stressful incident, Ashburner was at the Celera jamboree playing happily in the toybox that was the fruitfly genome, exhilarating in the new knowledge and even joshing with Venter. At one point, while celebrating the end of the

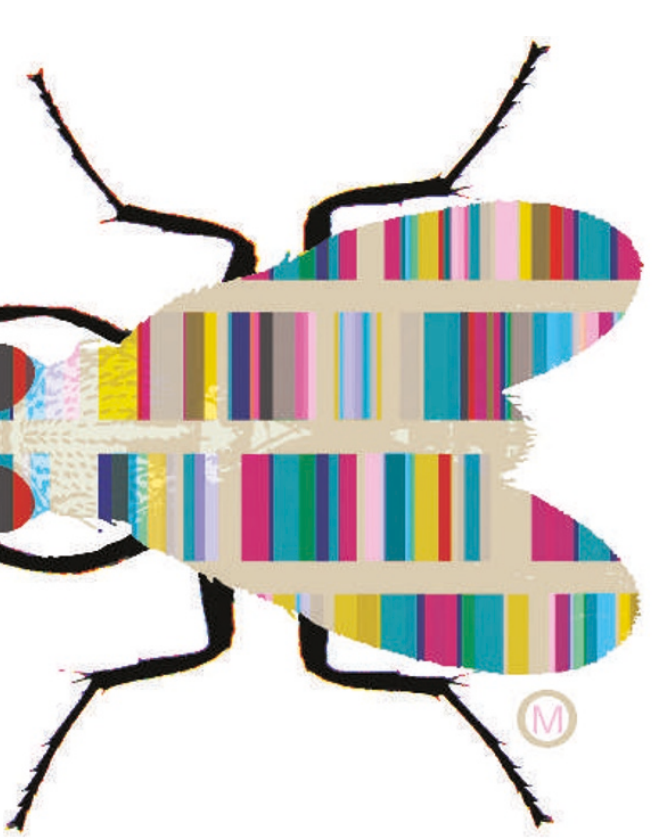

jamboree, Ashburner persuaded Venter to pose in headphones like a NASA flight director in Celera's mission-control room.

The history of genome sequencing drives home the message that science is usually the daughter, not the mother, of technology. Sequencing the human, fruitfly and all other genomes was made possible by new machinery. The resulting information was a glorious and far-reaching addition to human knowledge, but only a distant harbinger of new commercial applications. But at least it has generated some enjoyable literature, of which this is a good example.

Matt Ridley is at Blagdon, Seaton Burn,

Newcastle upon Tyne NE13 6DD, UK. His

biography of Francis Crick will be published in

June. www.mattridley.co.uk 